\title{
Evaluation of biocompatibility of veneered Bio HPP and veneered lithium disilicate crowns in anterior zone (Randomized controlled clinical trial)
}

Avaliação da biocompatibilidade de coroas de Bio HPP e coroas de dissilicato de lítio na região anterior (ensaio clínico controlado randomizado)

\author{
Esra'a ODEH $^{1}$, Hesham ALANSARY ${ }^{2}$, Ahmed NAGUIB ${ }^{2}$, Maha TAYMOUR ${ }^{2}$ \\ 1 - Faculty of Oral and Dental Medicine, MTI University, Cairo, Egypt. \\ 2 - Faculty of Dentistry, Cairo University, Cairo, Egypt.
}

\section{ABSTRACT}

Objective: Evaluation of the biocompatibility of BioHigh PerformancePolymer (Bio HPP) crownsveneered with Visio-Ling versus e.max crowns veneered with e.max veneering system. Material and Methods: 42 full-coverage crowns were fabricated for maxillary anterior teeth. A swap was obtained using a sterile paper cone to determine bacterial count and type. Pocket depth (PD) was determined using a William Periodontal probe. Measurements were repeated after 3, 6, 9 and 12 months respectively. Patients were randomly divided into: Group A fabricated from IPS e.max crowns and Group B fabricated from Bio HPP crowns. The preparations were standardized with an equi-gingival, finish line. Fisher's test was used to compare between the two groups. The significance level was set at $\mathrm{P} \leq 0.05$. Statistical analysis was performed with Windows, Version 23.0. (IBM SPSS Statistics) Armonk, NY: IBM Corp. Results: Bio HPP and e.max showed no statistically significant difference in bleeding on probing and PD except after 9and 12 months; Bio HPP showed statistically significantly higher PD than e.max (P-value $=0.027$, Effect size $=0.245$ ) and (P-value $=0.011$, Effect size $=0.310$ ), respectively. Fisher's test showed there was no statistically significant difference between total bacterial counts and the type of the two materials. Conclusion: Both e.max and Bio HPP crowns revealed successful biological behavior. No significant difference between the materials regarding the bacterial count and type as well as the pocket depth, however after 9 and 12 months, Bio HPP showed a higher significant difference PD than e.max.

\section{KEYWORDS}

Biocompatibility; Bio HPP; e.max; Pocket depth; Bacteria.

\section{RESUMO}

Objetivo: Avaliação da biocompatibilidade de coroas de Polímero Bio-High Performance (Bio HPP) estratificadas com Visio-Ling versus coroas e.max estratificadas com sistema de estratificação e.max. Material e Métodos: 42 coroas totais foram confeccionadas para dentes anteriores superiores. Uma amostra foi obtida usando um cone de papel estéril para determinar a contagem e o tipo de bactérias. A profundidade de bolsa (PD) foi determinada usando uma sonda periodontal de William. As medições foram repetidas após 3, 6, 9 e 12 meses, respectivamente. Os pacientes foram divididos aleatoriamente em: Grupo A fabricado com coroas IPS e.max e Grupo B fabricado com coroas Bio HPP. As preparações foram padronizadas com uma linha de término no nível da gengiva marginal. $\mathrm{O}$ teste de Fisher foi usado para comparação entre os dois grupos. O nível de significância foi estabelecido em $P \leq 0,05$. A análise estatística foi realizada com Windows, versão 23.0. (IBM SPSS Statistics) Armonk, NY: IBM Corp. Resultados: Bio HPP e e.max não mostraram nenhuma diferença estatisticamente significativa no sangramento à sondagem e PD, exceto após 9 e 12 meses; Bio HPP mostrou PD estatisticamente significativa maior do que e.max (valor $\mathrm{P}=0,027$, tamanho do efeito $=0,245$ ) e (valor $\mathrm{P}=0,011$, tamanho do efeito $=0,310$ ), respectivamente. $\mathrm{O}$ teste de Fisher mostrou que não houve diferença estatisticamente significativa entre as contagens bacterianas totais e o tipo dos dois materiais. Conclusão: As coroas e.max e Bio HPP revelaram comportamento biológico bem-sucedidos. Não houve diferença significativa entre os materiais em relação à contagem e tipo de bactérias, bem como à profundidade da bolsa, no entanto, após 9 e 12 meses, o Bio HPP apresentou uma diferença significativamente mais elevada de PD do que e.max.

\section{PALAVRAS-CHAVE}

Biocompatibilidade; Bio HPP; e.max; Profundidade do bolsa; Bactérias. 


\section{INTRODUCTION}

T or a successful outcome such as proper I esthetics, function, and relaxation of the orofacial structures the health of periodontium plays an important role and is required for all prosthetic and restorative therapies [1].

For many years, thoroughly investigations have been done to study the relationship between dental restorations and periodontal health [1]. The biocompatibility of a dental material refers to the ability of a material to produce a favorable host response during its expected use. [2].

Periodontal disease has many causes, and the existence of dental restorative materials is considered as one of those reasons. Restorative materials have different surface properties such as the surface energy inherent in the materials, surface roughness and the location of restorative margin $[3,4]$. Theses are believed to be some reasons why plaque adhere better to restoration than to enamel.

Several studies showed varying degree of bacterial colonization when they compared different restorative material to each other or teeth. Furthermore, studies stated that the biological outcome was analyzed by assessing probing depth and plaque level [5].

Several investigations undoubtedly show that there is marked increase in gingival lesions and gingival recession as a result of the migration of metal ions from prosthetic work. In this context, the new Bio HPP material opens new perspective in solving prosthetic failures. The restorations made from polymer Bio HPP convinced users that it is one of the best solutions on market today [6].

Bio-HPP (High Performance Polymer) is a PEEK variant that has been specially optimized for the dental field. Bio-HPP has been strengthened with special ceramic filler (grain size of 0.3 to $0.5 \mu \mathrm{m}$ ) allowing its use in the crown and bridge area. Due to the very small grain size, constant homogeneity can also be produced which is an important prerequisite for these outstanding material properties and forms the basis for consistent quality. In addition, Bio-HPP has an extremely good polishing property with a high shine thanks to the fine granularity of the filler. This property minimizes the deposition of plaque and the degree of discoloration. Moreover the E-modulus of Bio-HPP falls in the range of $4 \mathrm{GPa}$, which closely resembles the elasticity of human bone, Bio HPP is also useful for patients with allergies because of its very low water solubility of $<0.3 \mu \mathrm{g} / \mathrm{mm} 3$.Bio HPP can be manufactured either by CAD/CAM or the conventional lost wax press technique. Moreover, the white framework material can be veneered with visio.lign as it has good bond strength and most importantly has shock absorbing effect on occlusion. Therefore Bio-HPP enhance esthetic and clinical outcome [79].

The IPS e-max ceramic is properly documented in the literatures as a highly successful restoration material, offering excellent esthetic and biological outcome in addition to its ability to achieve high patient satisfaction $[10,11]$.

Numerous studies have investigated the biocompatibility of dental restorative materials and have developed a variety of testing systems for the evaluation of the biological effects of these materials [12]. However, little studies were made to determine the biocompatibility of Bio HPP material used in prosthetic dentistry.

Therefore the purpose of this study was to clinically evaluate the biocompatibility (bleeding on probing) as well as the bacterial count and type in addition to the pocket depth of e.max and Bio Hpp crowns.

The null hypothesis of this study was that there would be no difference in the biological outcome of e.max restoration when compared with Bio HPP restorations for anterior teeth. 


\section{MATERIALS AND METHODS}

\section{Approval and Ethical considerations}

This randomized clinical trial was conducted in the in Faculty of Dentistry, Department of Fixed Prosthodontics, Cairo University. The ethical approval was acquired from the Ethics Committee of Scientific Research - Faculty of Dentistry - Cairo University (approval no: 161022). Participation in the study was voluntary and informed consent was received from all of them before starting the treatment regarding treatment plan sequence, publishing of their results and pictures.

\section{Registered}

This studied was registered at the Clinical Trials.gov registry under the registration number NCT02929199 on October 11, 2016.

\section{Study design}

A randomized double blind controlled clinical trial with a 1:1 allocation ratio.

\section{Sample size estimation}

In reference to a previous studies by Julious SA (2009) [13] and Wolfart et al (2009) [14] a total sample size of 42 patients are required to be $80 \%$ sure that the limits of a two-sided $90 \%$ confidence interval will exclude a difference between the standard and experimental group of more than 20\%. Done by Sealed Envelope Ltd (2016) [15].

\section{Participant's selection}

All participants fulfilled the following inclusion criteria, age range from 20-40 years old with healthy physical status, good oral hygiene and motivation. Patients with normal occlusion, having an upper anterior teeth indicated for full coverage with at least $1 \mathrm{~mm}$ of tooth structure above the gingiva and no active periodontal, pulp or apical lesions were recruited from July 2018 till September 2018 from the Fixed Prosthodontics Department outpatient clinic, Faculty of Dentistry, Cairo University, Cairo, Egypt. Screenings of patients were carried out until target number was reached. This study ended on November 2019. All patients were requested to provide a full medical and dental history.

\section{Allocation concealments}

In each group, a number for each member was written on a white paper and placed inside an opaque sealed envelopes from inside and nothing is coded from outside.

\section{Implementation}

All procedures were done by the same operator

\section{Randomization method}

Randomization was carried out in the Center of Evidence Based Dentistry, Cairo University using computerized sequence generation (https:// www.randomizer.org) Participants were divided into groups (A and B) .Each participant was given a sealed envelope which contained their randomized number. Group A received e.max crowns while group B received Bio Hpp crowns.

Table I - Sample grouping

\begin{tabular}{|c|c|c|}
\hline $\begin{array}{c}\text { Group(A) } \\
\text { Control group }\end{array}$ & $\begin{array}{c}\text { Group(B) } \\
\text { Intervention group }\end{array}$ & $\begin{array}{l}\text { Total number of } \\
\text { crowns }\end{array}$ \\
\hline $\begin{array}{l}\text { e.max press crowns } \\
(n=21)\end{array}$ & $\begin{array}{l}\text { Bio HPP crowns } \\
\qquad(n=21)\end{array}$ & $(n=42)$ \\
\hline
\end{tabular}

\section{Blinding}

The outcome assessors (prosthodontics colleagues) and the participants were blind (double blinding) to the material while the operator (the researcher) will not due to the difference in restorative material presentation and application protocol.

\section{Intervention}

Two different materials (Bio HPP with Visio.Lign veneering composite resin and e.max with e.max veneering system were selected for fabrication of single anterior crowns in this study. All procedures were carried out by the 
same candidate. The prosthodontics procedures were done in 5 visits in the clinics of Faculty of Dentistry, Fixed Prosthodontics Department, Cairo University, Cairo, Egypt.

\section{Visit 1}

\section{Diagnostic phase}

Dental examination, periodontal evaluation, symmetry of gingival level, oral hygiene, dental caries and parafunctions were assessed. Scaling and polishing was done for each patient to remove dental plaque and calculus that could affect the final outcome. Pre-operative photographs for each patient were taken. (Figure 1)

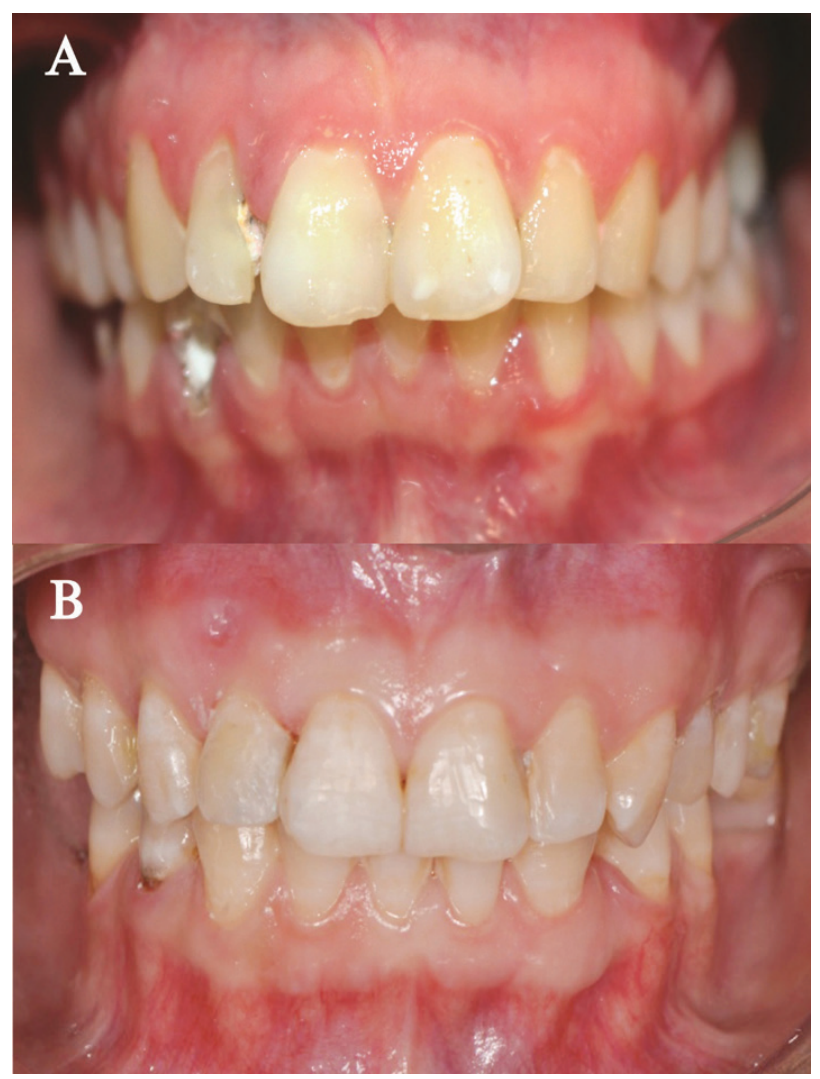

Figure 1 - Representative pre-operative photos of each investigated group. (A): Case of group (A). (B): Case of group (B).

Alginate impressions (Tropicalgin, Zhermack, Italy) for both arches were taken and poured with GC FUJIROCK EP, GC, America, type IV dental stone for diagnostic cast and study cast.
After oral hygiene measures the first microbial samples were collected from the gingival crevice in labial surface of the abutments and this was considered as pre-operative measure. The gingiva around the teeth was air dried. Sulcular samples were taken using a sterile paper cone placed into the sulcus for $15 \mathrm{~s}$. (Figure 2) Samples were stored and transferred in a transport medium (STM) it to the microbiology laboratory. Sterile cones were taken out of the transport tubes using sterile forcipes. The samples were diluted in sterile broth (liquid medium used for the cultivation of a wide variety of microorganisms, including aerobic and anaerobic bacteria) $100 \mu \mathrm{l}$ from 10-10, 10-100 were placed on the surfaces of plates of brain heart infusion agar and macconkey agar (HIMEDIA ${ }^{\circledR}$ Agar) (later material used to determine the count of gram -ve bacteria while the former determines total count of bacteria whether it was aerobic or anaerobic). The plates were incubated for 24 hours at $37^{\circ} \mathrm{C}$.

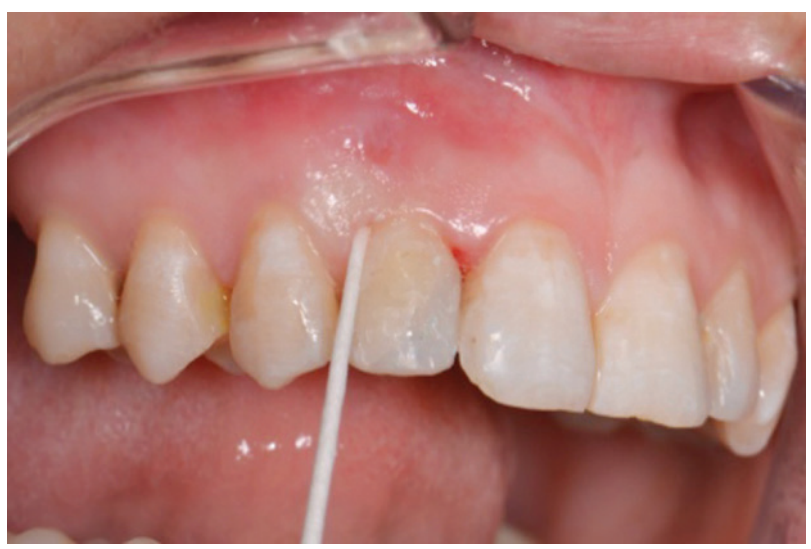

Figure 2 - Sample collected from margin \& sulcus of tooth by sterile paper cone.

Brain heart agar plates were incubated at $10 \% \mathrm{CO} 2$ atmosphere with Gas-pak in a jar. (Gas-pak is a method used in the production of an anaerobic environment).Total numbers of colonies were counted after 48 hours incubation period and the viable count was determined. The isolated colonies were further processed and identified microscopically [16]. (Figure 3) 

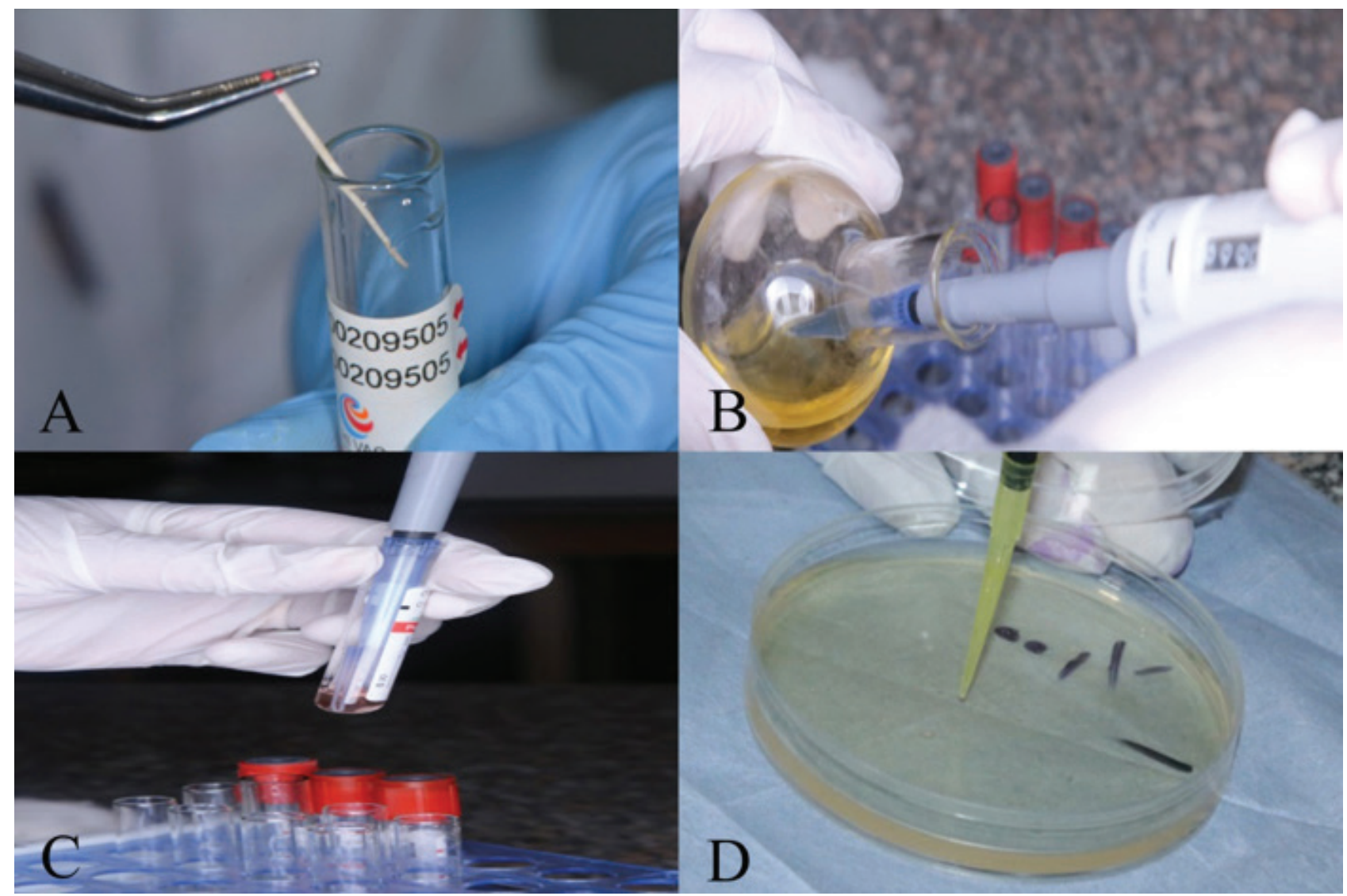

Figure 3 - (A-D) Represents steps how sample was prepared.

Pocket depth was measured using graduated William's periodontal probe at disto-buccal, midbuccal, mesio-buccal, disto-lingual, mid-lingual and mesio-lingual [17]. The probe was inserted parallel to the long axis to the tooth and was measured according from the free gingival margin to the level of attachment of the periodontium and deepest penetration of periodontal probe. (Figure 4)

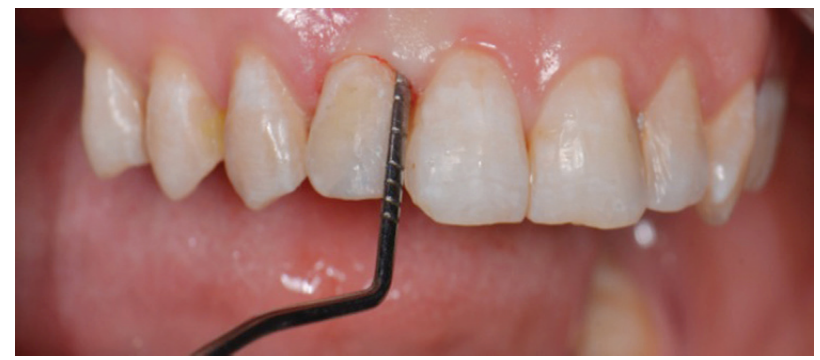

Figure 4 - Pocket depth measurement using Williams's periodontal probe.
The tooth color was determined using VITA 3D-Master and Vita Classic shade guide system (VITA, Zahnfabrik, Germany)

\section{Visit 2}

\section{Tooth preparation}

To standardize tooth preparation and ensure equal thickness, vertically orient grooves were made on the labial, lingual and incisal surface .The remaining island of the enamel was removed using do a tapered diamond stone with a round end to produce $1 \mathrm{~mm}$ equi-gingiva deep chamfer finish line with axial reduction of 1-1.5 mm and occlusal reduction of $1.5-2 \mathrm{~mm}$. Beveling of the incisal surface was performed with $45^{\circ}$ to the long axis of the tooth with the tapered diamond stone with round end. The amount preparation was verified with the silicon index. 
All sharp line angles that might serve as a point for stress concentration were rounded. (Figure 5)

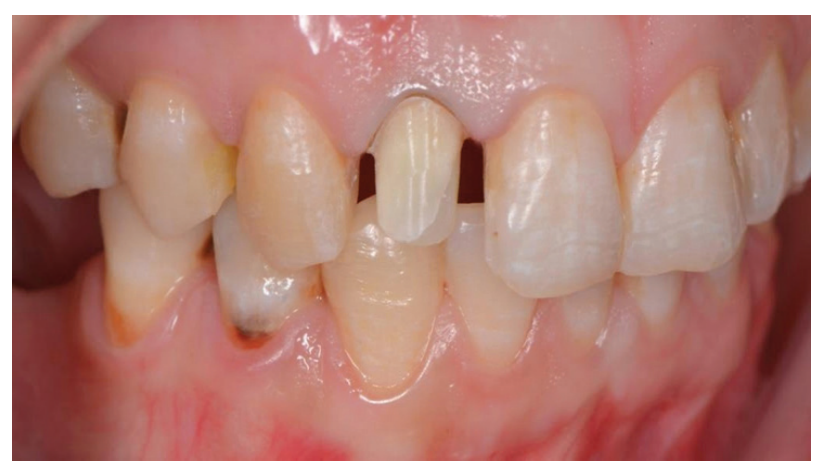

Figure 5 - representative preparation photo after finishing.

\section{Visit 3}

\section{Impression making}

A retraction cord was used to allow accurate impression making. Final impression was taken using vinyl polysiloxane addition silicon (Elite HD, Zhermack Italy) in plastic stock trays. Temporarozation using silicone index filled with bis-acrylate resin composite material and placed on the lubricated teeth intra-orally. After setting, the temporary restoration was finished, polished and cemented using Rely X Temp NE (3MESPE, USA ) non-eugenol, acrylic-urethane polymer based temporary cement.

\section{Designing of the crowns}

Once the dental laboratory received the final impression, the master cast was poured with a type IV dental stone according to manufacturer's instruction to produce the master cast.

An extra-oral scanner (InEos X5, Cerec, Sirona) was used to scan the master cast and a three-dimensional image was obtained for abutment tooth on the computer screen. Using Exocad software, designing of the Bio HPP copings was done. The cement space was set by the software to be 50 microns. Using 5-axis milling machine the try in crowns were milled from the PMMA blocks.

\section{Visit 4}

\section{Try in \& Provisionalization}

The try-in was performed by using the CAD/ CAM milled Polymethyl methacrylate (PMMA). The CAD/CAM PMMA was initially tried to check marginal fit, shape, contacts, contour and then the overall integration with the lips and finally with the teeth face. This was then used as the provisional restoration.

\section{Construction of Bio HPP crowns:}

The CAD/CAM wax-patterns coping were produced according to the virtual image designed by the Exocad. The wax patterns were milled with a milling machine (cam 5-s1 impression) from a wax disc.

Bio HPP was supplied in the form of granules to fabricate tooth shape supported framework by pressing technology in the 2 press System then veneered with Visio.Lign composite system of appropriate shade according to manufacturer instruction.

Conditioning of the copings was done by blasting them with $110 \mu \mathrm{m}, 2-3$ bar pressure $\mathrm{Al} 2 \mathrm{O} 3$ powder at $0.25 \mathrm{MPa}$, from a distance of $10 \mathrm{~mm}$ and at an angle of $45^{\circ}$. Visio.link primer was applied and polymerized for 90 seconds by a special light polymerization device (wavelength: 370-500 nm, intensity: $220 \mathrm{~mW} / \mathrm{cm} 2$ )

Veneering of BioHPP copings was done in 3 steps according to manufacturer instructions, opaque, body and neck (dentin) and incisal edge. Each layer was polymerized for 180 second with a light polymerization device.

Crea.lign modeling liquid was used during layering as it serves as modifier regarding viscosity and modulus of elasticity. The crown was characterized by Visio.paint stains and polymerized for 180 seconds.

Finally BioHPP PEEK crowns were polished using Acrypol polishing paste and Visio. lign polishing Kit. They ensure a perfect finish and 
surfaces with high plaque resistance and shade stability.

\section{Construction of e.max crowns}

Lithium Disilicate (e.max) ceramic were supplied in the form of ingots to fabricate tooth shape supporting framework by pressing technology then veneered with Lithium Disilicate Ceram of appropriate shade.

The sprue was attached to the wax copying. IPS Press VEST premium, with the corresponding IPS Investment Ring System and matching ring gauge were used for investment. After setting, the investment ring was placed in Programat EP 3010 (Ivoclar Vivadent Liechtenstein) preheating furnace. The burnout reached $850^{\circ} \mathrm{C}$ and left for $45 \mathrm{~min}$. The IPS e.max ingot was placed into the hot investment ring. After cooling to room temperature (approximately 60 minutes), divesting was carried out. Finishing was done using a low speed and light pressure sprue was separated using Dyrex Brilliant, separating disk $0.25 \mathrm{~mm}$.

The outer side of the restoration was cleaned by blasting with air abrasion type $100 \mathrm{Al} 2 \mathrm{O} 3$ at 1 bar (15 psi) pressure and then cleaned with the steam cleaner. Veneering using ceram veneering system was done according to manufacturer instructions.

\section{Visit 5}

\section{Restoration cementation}

Prophylaxis paste and polishing brush mounted was used for cleaning the tooth surfaces prior to bonding following removal of provisional restoration. Then, isolation was granted through the use of rubber dam.

The fitting surfaces of Bio HPP crowns were conditioned by blasting the restorations at 2 to 3 bar blasting pressure with aluminum oxide (110 $\mu \mathrm{m}$ and "Visio.link" primer) was applied and subsequent polymerized for 90 seconds with a light polymerization device in accordance with the "Visio.link" processing instructions.
Luting self-adhesive resin cement BisCem ${ }^{\circledR}$, Bisco , U.S.A was used for cementation. The crown was seated to the tooth in position till complete seating using finger pressure. Excess cement was removed using a sharp explorer and waxed dental floss. (Figure 6)

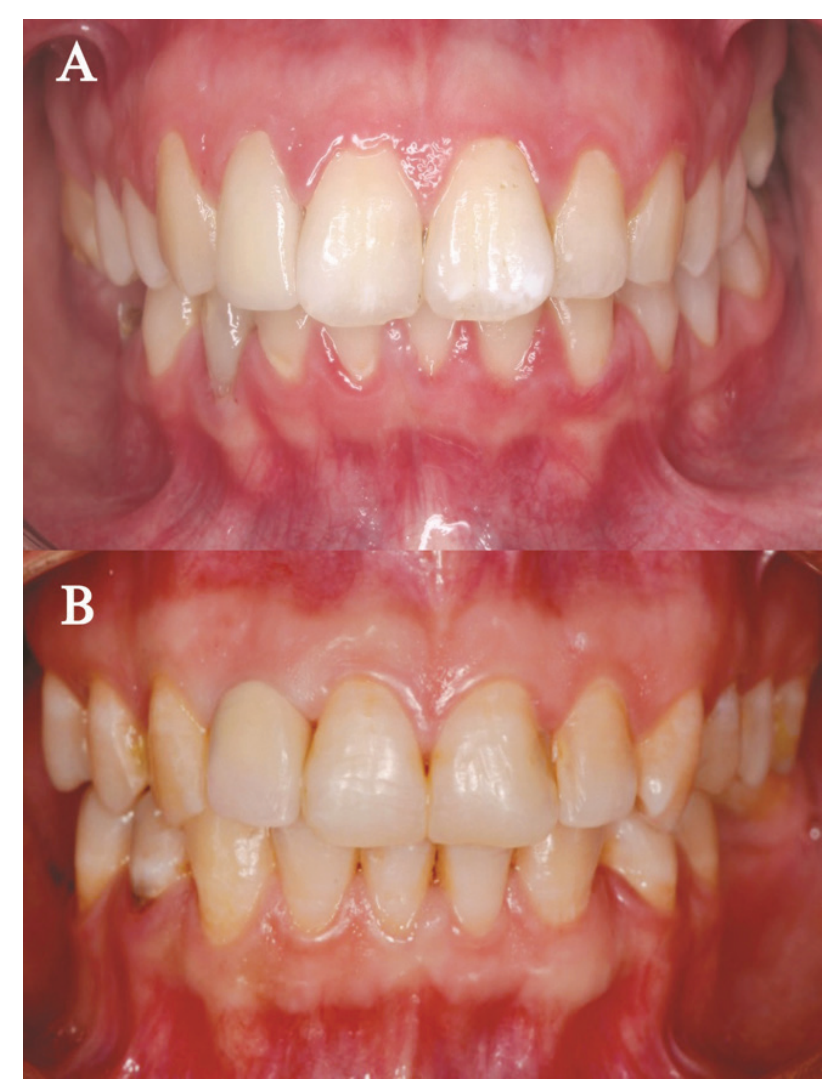

Figure 6 - Representative post-operative photos of each investigated group after cementation. (A): Case of group (A). (B). Case of group (B).

\section{Postoperative instruction and care}

The patients were instructed to perform brushing and flossing regularly using non-abrasive tooth paste and soft brush.

\section{Follow up sessions}

Recall examinations were performed to all patients post cementation after 3,6,9 and 12 months.

Patients were provided with a questionnaire to fill during the visit. 
Pocket depth measurement and sample collection were measured in the same way as mentioned previously.

\begin{tabular}{|c|c|c|}
\hline \multicolumn{3}{|c|}{ Patient satisfaction questionnaire for bleeding } \\
\hline \multicolumn{3}{|c|}{ Patient Name: } \\
\hline \multicolumn{3}{|l|}{ Age: } \\
\hline \multicolumn{3}{|l|}{ Gender: } \\
\hline \multicolumn{3}{|c|}{ Telephone Number: } \\
\hline \multicolumn{3}{|c|}{ 1. Do you use a tooth brush? } \\
\hline 口Yes & $\square$ No & \\
\hline \multicolumn{3}{|c|}{ 2. If yes, how many times a day? } \\
\hline 마 & $\square 2$ & $\square$ Several \\
\hline \multicolumn{3}{|c|}{ 3. Bleeding while brushing. } \\
\hline QYes & $\square$ No & \\
\hline \multicolumn{3}{|c|}{ 4. Do you rinse your mouth after food? } \\
\hline QYes & $\square$ No & \\
\hline \multicolumn{3}{|c|}{ 5. Do you use mouthwash? } \\
\hline QYes & $\square$ No & \\
\hline
\end{tabular}

Figure 7 - Questionnaire for evaluating patient satisfaction.

Table II - Outcome measures, measuring devices and measuring unit

\begin{tabular}{|cccc|} 
Outcome measure & $\begin{array}{c}\text { Outcome } \\
\text { Measuring } \\
\text { Device }\end{array}$ & $\begin{array}{c}\text { Outcome } \\
\text { Measuring } \\
\text { Unit }\end{array}$ \\
\hline $\begin{array}{c}\text { Primary } \\
\text { Outcome }\end{array}$ & $\begin{array}{c}\text { Biocompatibility } \\
\text { (bleeding) }\end{array}$ & $\begin{array}{c}\text { Questionnaire } \\
\text { (present or absent) }\end{array}$ & Binary data \\
\hline $\begin{array}{c}\text { Secondary } \\
\text { Outcome }\end{array}$ & $\begin{array}{c}\text { Sulcus depth } \\
\text { Bacteria colonization: } \\
\text { 1.Type } \\
\text { 2.Total count }\end{array}$ & Periodontal probe & Millimeter \\
& Culture & Cells per millimeter \\
\hline
\end{tabular}

\section{Statistical analysis}

Numerical data were explored for normality by checking the distribution of data and using tests of normality (Kolmogorov-Smirnov and Shapiro-Wilk tests). All data showed normal (parametric) distribution. Numerical data were presented as mean and standard deviation (SD) values. Two-way repeated measures ANOVA was used to compare between the experimental and control sides, the two materials as well as the changes by time within each group. For pair-wise comparisons, Bon ferroni's post-hoc test was used when ANOVA test is significant. Qualitative data were presented as frequencies and percentages. Fisher's test was used to compare between the two groups. The significance level was set at $\mathrm{P} \leq 0.05$. Statistical analysis was performed with IBM SPSS Statistics for Windows, Version 23.0. Armonk, NY: IBM Corp.

\section{RESULTS}

1. Pocket depth Comparison between the groups

Pre-operatively, after 3 and 6 months; there was no statistically significant difference between the mean PD at the two sides (P-value $=0.462$, Effect size $=0.030)$, (P-value $=0.231$, Effect size $=0.079)$ and $(\mathrm{P}$-value $=0.173$, Effect size $=$ 0.101), respectively.

After 9 as well as 12 months; Bio HPP showed statistically significantly higher mean $\mathrm{PD}$ than e.max (P-value $=0.027$, Effect size $=$ $0.245)$ and $(P$-value $=0.011$, Effect size $=0.310)$, respectively. (Figure 8 )

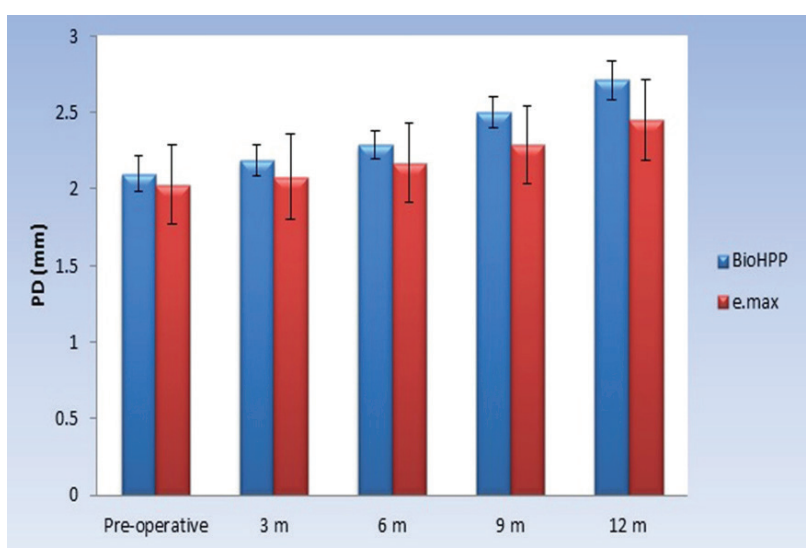

Figure 8 - A representative bar chart showing the mean and standard deviation values for PD at Bio HPP and e.max sides. 
Table III - Descriptive statistics and results of two-way ANOVA test for comparison between Pocket Depth (PD) of Bio HPP and e.max crowns

\begin{tabular}{|ccccccc}
\hline Time & \multicolumn{2}{c}{$\begin{array}{c}\text { Bio HPP } \\
(\mathbf{n = 2 1 )}\end{array}$} & \multicolumn{2}{c}{$\begin{array}{c}\text { e.max } \\
(\mathbf{n = 2 1 )}\end{array}$} & $\begin{array}{c}\text { P- } \\
\text { value }\end{array}$ & $\begin{array}{c}\text { Effect } \\
\text { size }\end{array}$ \\
\hline Mean & SD & Mean & SD & & \\
\hline Pre-operative & 2.1 & 0.12 & 2.03 & 0.26 & 0.462 & 0.030 \\
\hline $3 \mathrm{~m}$ & 2.19 & 0.1 & 2.08 & 0.28 & 0.231 & 0.079 \\
\hline $6 \mathrm{~m}$ & 2.29 & 0.09 & 2.17 & 0.26 & 0.173 & 0.101 \\
\hline $9 \mathrm{~m}$ & 2.5 & 0.1 & 2.29 & 0.25 & $0.027^{\star}$ & 0.245 \\
\hline $12 \mathrm{~m}$ & 2.71 & 0.13 & 2.45 & 0.26 & $0.011^{\star}$ & 0.310 \\
\hline
\end{tabular}

*: Significant at $\mathrm{P} \leq 0.05$

B. Comparison of total bacterial count and type between both groups

\section{Total Bacterial count Comparison between the two materials}

Pre-operatively, after 3, 6, 9 and 12 months; The mean $\log _{10}$ CFU of total bacterial counts of the two materials showed no statistically significant difference. (P-value $=$ 0.085, Effect size $=0.184)$, (P-value $=0.099$, Effect size $=0.171),($ P-value $=0.133$, Effect size $=0.144),(P-v a l u e=0.129$, Effect size $=0.147)$ and $($ P-value $=0.175$, Effect size $=$ 0.119), respectively. (Figure 9)

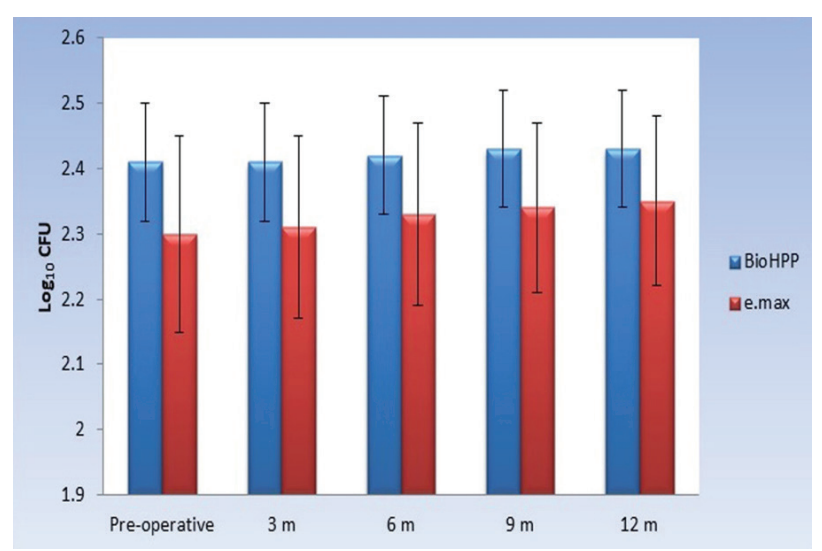

Figure 9 - Representative bar chart showing the mean and standard deviation values for Log10 CFU of total bacterial counts at Bio HPP and e.max sides.
Table IV - Descriptive statistics and results of the two-way ANOVA test for comparison between Log $_{10}$ CFU of total bacterial counts in Bio HPP and e.max sides (1/10 concentration)

\begin{tabular}{|c|c|c|c|c|c|c|}
\hline \multirow{2}{*}{ Time } & \multicolumn{2}{|c|}{$\begin{array}{l}\text { Bio HPP } \\
(n=21)\end{array}$} & \multicolumn{2}{|c|}{$\begin{array}{c}\text { e.max } \\
(n=21)\end{array}$} & \multirow{2}{*}{$\begin{array}{c}\mathrm{P}- \\
\text { value }\end{array}$} & \multirow{2}{*}{$\begin{array}{c}\text { Effect } \\
\text { size }\end{array}$} \\
\hline & Mean & SD & Mean & SD & & \\
\hline Pre-operative & 2.41 & 0.09 & 2.3 & 0.15 & 0.085 & 0.184 \\
\hline $3 m$ & 2.41 & 0.09 & 2.31 & 0.14 & 0.099 & 0.171 \\
\hline $6 m$ & 2.42 & 0.09 & 2.33 & 0.14 & 0.133 & 0.144 \\
\hline $9 m$ & 2.43 & 0.09 & 2.34 & 0.13 & 0.129 & 0.147 \\
\hline $12 m$ & 2.43 & 0.09 & 2.35 & 0.13 & 0.175 & 0.119 \\
\hline
\end{tabular}

*: Significant at $\mathrm{P} \leq 0.05$.

\section{(Aerobic)}

Bacteria Type (Anaerobic +ve \& -ve)/

Anaerobic Gram + ve bacteria comparison between the two materials

Pre-operatively, after 3, 6, 9 and 12 months; showed no statistically significant difference between mean $\log _{10}$ CFU of anaerobic Gram + ve bacteria at the two materials' sides (P-value $=0.219$, Effect size $=0.099),(P$-value $=0.343$, Effect size $=0.060),(P$-value $=0.412$, Effect size $=0.045),(P$-value $=0.258$, Effect size $=0.084)$ and $(\mathrm{P}$-value $=0.481$, Effect size $=0.034$ ), respectively. (Figure 10)

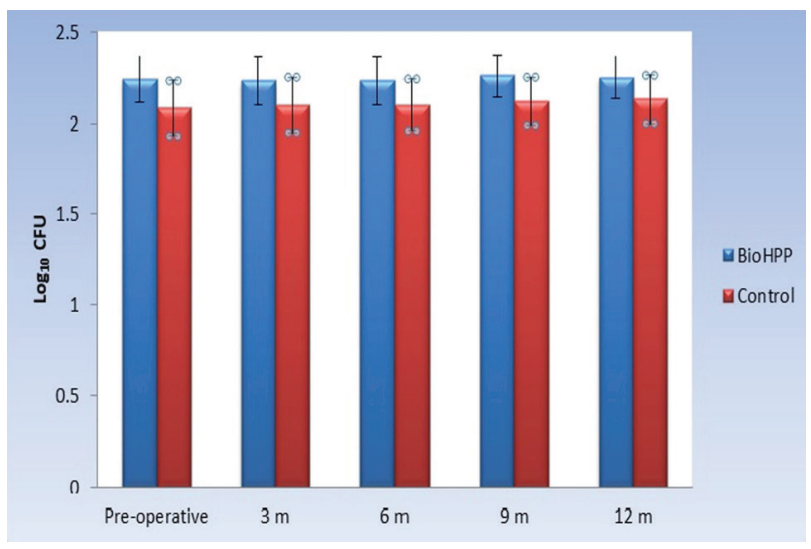

Figure 10 - Representative bar chart showing the mean and standard deviation values for Log10 CFU of anaerobic Gram Uvve bacteria at Bio HPP and e.max sides. 
Table V - Descriptive statistics and results of two-way ANOVA test for comparison between $\log _{10}$ CFU of anaerobic Gram + ve bacteria in Bio HPP and e.max sides

\begin{tabular}{|ccccccc|}
\hline Time & \multicolumn{2}{c}{$\begin{array}{c}\text { Bio HPP } \\
(\mathbf{n = 2 1 )}\end{array}$} & \multicolumn{2}{c}{$\begin{array}{c}\text { e.max } \\
(\mathbf{n = 2 1})\end{array}$} & $\begin{array}{c}\text { P- } \\
\text { value }\end{array}$ & $\begin{array}{c}\text { Effect } \\
\text { size }\end{array}$ \\
\hline & Mean & SD & Mean & SD & & \\
\hline Pre-operative & 2.24 & 0.13 & 2.13 & 0.19 & 0.219 & 0.099 \\
\hline $3 \mathrm{~m}$ & 2.23 & 0.13 & 2.15 & 0.19 & 0.343 & 0.060 \\
\hline $6 \mathrm{~m}$ & 2.23 & 0.13 & 2.16 & 0.19 & 0.412 & 0.045 \\
\hline $9 \mathrm{~m}$ & 2.26 & 0.12 & 2.17 & 0.18 & 0.258 & 0.084 \\
\hline $12 \mathrm{~m}$ & 2.25 & 0.12 & 2.19 & 0.17 & 0.481 & 0.034 \\
\hline & & & & & & \\
\hline
\end{tabular}

\section{Anaerobic Gram -ve bacterial counts}

Anaerobic Gram -ve bacteria was found in only one Bio HPP crown after 3 months and three Bio HPP crowns after 6 months, five Bio HPP crowns after 9 months and six Bio HPP crowns after 12 months. As regards e.max crowns; Gram -ve bacteria was found in only one e.max crown after 3 months, two e.max crowns after 6 months, 9 months and 12 months.

Statistical comparisons regarding Gram -ve bacteria was not performed due to this few numbers of cases showed presence of these bacteria.

\section{Aerobic bacteria comparison between the two materials}

Pre-operatively, after 3, 6, 9 as well as 12 months there was no statistically significant difference between mean $\log _{10}$ CFU of aerobic bacteria at the two materials' sides. (Figure 11)

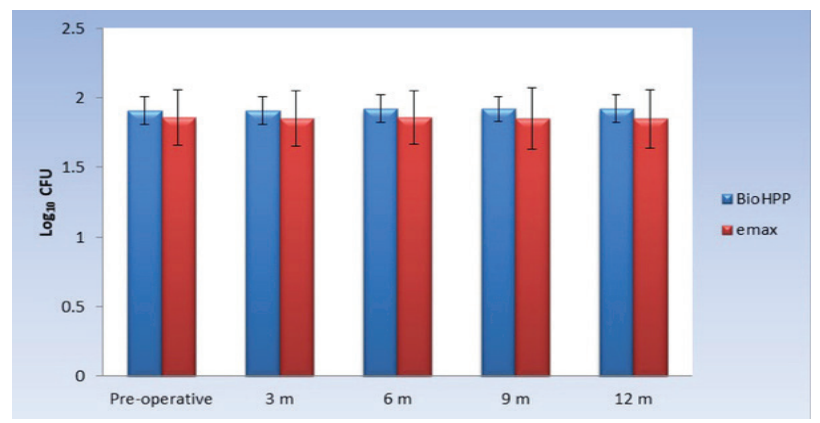

Figure 11 - Representative bar chart showing the mean and standard deviation values for Log10 CFU of aerobic bacteria at Bio HPP and e.max sides.
Table VI - Descriptive statistics and results of two-way repeated measures ANOVA test for comparison between $\log _{10}$ CFU of aerobic bacteria in Bio HPP and e.max sides

\begin{tabular}{|c|cccccc|}
\hline & \multicolumn{2}{|c}{$\begin{array}{c}\text { Bio HPP } \\
(\mathbf{n = 1 0})\end{array}$} & \multicolumn{2}{c|}{$\begin{array}{c}\text { emax } \\
(\mathbf{n = 1 0})\end{array}$} & $\begin{array}{c}\text { P- } \\
\text { value }\end{array}$ & $\begin{array}{c}\text { Effect } \\
\text { size }\end{array}$ \\
\hline & Mean & SD & Mean & SD & value \\
\hline Pre-operative & 1.91 & 0.1 & 1.86 & 0.2 & 0.471 & 0.035 \\
\hline $3 m$ & 1.91 & 0.1 & 1.85 & 0.2 & 0.421 & 0.044 \\
\hline $6 m$ & 1.92 & 0.1 & 1.86 & 0.19 & 0.427 & 0.043 \\
\hline $9 m$ & 1.92 & 0.09 & 1.85 & 0.22 & 0.374 & 0.053 \\
\hline $12 m$ & 1.92 & 0.1 & 1.85 & 0.21 & 0.374 & 0.053 \\
\hline
\end{tabular}

\section{DISCUSSION}

IPS e.max and Bio HPP crowns both revealed no significant difference in their bacterial count and type as well as the pocket depth. However after 9 and 12 months, Bio HPP showed higher significant difference $P D$ than e.max but both IPS e.max and Bio HPP crowns revealed successful biological behavior. Thus, the first part was with the hypothesis while the second part was against.

The oral cavity has heterogeneous environments for microbial colonization, areas such as the lips, cheek, palate, and tongue, teeth and gingival sulcus.1300 species are found in the gingival crevice and nearly 1,000 species comprise dental plaque [18]. Different temperatures, diet, $\mathrm{pH}$ and feeding habits are important factors that contribute in the establishment of oral microbiome.

There was no statistically significant difference between the two materials regarding the total bacteria count and type (aerobic and anaerobic Gram + ve bacteria) when determined pre-operatively, after 3, 6, 9 and 12 months. This could be due to highly finished and polished surfaces protocol followed in the study for both materials.

This is in accordance with Stock et al. (2016) [19] who reported that PEEK had less Bleeding on probing, plaque index and pocket 
depths. Heimer et al. (2016) [20] also found that PEEk provides low plaque accumulation thus may be an acceptable material. Bechier et al. (2016) [7] also stated that Bio HPP, is associated with a high level of stability, very good polishing qualities, and a low affinity for plaque.

Explanation for similarity of Bio HPP crown to e.max, Visio-lign veneering system is a newly developed polymer material with ceramic filler. The ceramic micro-filler embedded in the polymer matrix increases the material's abrasion resistance, which comes very close to that of natural teeth .Visio-lign ensures resistance to plaque and shade stability since they harden completely at a temperature of $120^{\circ} \mathrm{C}$ and a pressure of 250 bars. Crea.lign modifying liquid contains only nano-fillers and no ground dental glass resulting in unsurpassed polishing properties. Hannig et al. (2007) [21] found that nano composite significantly reduced bio-film formation and accumulation.

Regarding the anaerobic Gram -ve bacteria type, found in only one Bio HPP crown after 3 months and three Bio HPP crowns after 6 months, five Bio HPP crowns after 9 months and six Bio HPP crowns after 12 months. As regards e.max crowns; Gram -ve bacteria was found in only one e.max crown after 3 months, two e.max crowns after 6 months, 9 months and 12 months. Due to vague number of gram -ve bacteria (10 or less) found indicates that the crowns did not induce a pathologic condition in peridontium during 1 year follow up period.

As explained also by Chakrabarty and Karim [22] who reported that the oral cavity was colonized by various microbial communities. A significant proportion of the colony was facultative or strict anaerobes. They stated that a there was a balance of the species within the community, known as "microbial homeostasis and If this balance was disrupted, the bio-film composition changes leading to the initiation of local infections that may ultimately lead to tooth loss. At the onset of the infections, the Gram-positive bacteria dominate the biofilm composition, but if left undisturbed, a more complex bio-film builds up where the Gramnegative anaerobic and proteolytic rods become dominant. The composition of the periodontitis bio-film differs from that of the gingivitis, as it is dominated by different Gram-negative rods most of which are anaerobic, proteolytic bacteria.

At the same time the pocket depth of e.max as well as Bio HPP showed that there was no statistically significant difference preoperatively, after 3 and after 6 months; between mean PD of the two materials, however after 9 and 12 months; Bio HPP showed a statistically significantly higher mean PD value than e.max. This could be due to change in surface roughness of restoration with time. This could be explained by the leaching of ions from the veneering material that lead to formation of micro or nano irregularities which acted as a niche for accumulation of the micro-organisms. Micro-organism release toxin which could irritate the gingival tissue or lead to change in the sequence of arrangement of bacteria colonization and deposition of gram -ve bacteria leading to increased intra-crevicular depth. This is accordance with the results in this study, appearance of gram -ve bacteria Bio HPP group despite no change in total bacteria count.

This was in agreement with Dantas et al. (2016) [23] who found that increased surface roughness was directly related to increase in bacterial adhesion. Specimens that are finished but not polished showed an increase in bacterial adhesion compared to those finished and polished. Specimens that are finished and polished by a laboratory protocol presented smoother surfaces and less bacterial adhesion as manual polishing tends to reduce the surface roughness of the material. 
This is also in accordance with Bolat et al. (2019) [24] who stated that the bacterial biofilm is formed in different ways depending on the type of material used to manufacture the dental crowns. They also stated that the number of bacteria that adhered to the dental crowns surface increased with time. On the other hand Juárez et al. (2015) [25] conflicted with these findings and stated that the periodontal conditions of the teeth rehabilitated with crowns do not differ from their contra lateral teeth.

In this study, most of the measured PDs for both materials were found to be $\leq 3 \mathrm{~mm}$ which indicated that in spite of the statistically significant difference between the crown sites after 9 and 12 months, clinically the crowns did not induce pathological pocketing. This is in accordance with Shi et al. (2018) [26] who stated probing depth in a healthy site is $\leq 3 \mathrm{~mm}$.

Based on the data collected from the patients in this study, there was no statistically significant difference between prevalence of bleeding in the two groups. One patient reported pregnancy approximately 6 months after cementation of the restoration. This could have modified the patient's hormones that could have affected the gingival response to brushing.

\section{Limitation}

The surface roughness of Bio HPP and e.max after finishing procedures should be evaluated. Further long term studies are required with long follow up period to evaluate biological performance of both restorations and whether Bio HPP survival is time dependent.

\section{Recommendations}

1. Further studies are required to improve the optical properties of the Peek material so it could be used as a monolithic restoration without veneering in esthetic zone.

2. Further investigations are required to improve the hardness the veneering material to prevent ion leaching.
3. Further long term studies are required to evaluate surface changes of Peek material that occur with time.

\section{CONCLUSION}

Within the limitations of this study, the following conclusions were drawn as follows:

1) Both IPS e.max and Bio HPP crowns revealed successful clinical performance from biological aspect and yield high patients satisfaction regardless of Bio HPP esthetic outcome.

2) No significant difference between the materials regarding the bacterial count and type as well as the pocket depth, however after 9 and 12 months, Bio HPP showed a higher significant difference PD than e.max. Thus, careful checking of the surface of the veneering material especially after 1 year from the restoration cementation and surface treatment or repair of the Visio.Lign veneering material should be considered to resolve the problem of micro or nano irregularities that may occur on the surface.

\section{Funding}

This study was partially supported by department of fixed prosthodontics, Faculty of Oral and Dental Medicine, Cairo University(Equipment units and some consumables)

\section{Conflict of interest}

The authors have no proprietary, financial, or other personal interest of any nature or kind in any product, service, and/or company that is presented in this article.

\section{Regulatory Statement}

This study was conducted in accordance with all the provisions of the local human subject's oversight committee guidelines and policies of: Ethics Committee of Scientific 
Research - Faculty of Dentistry - Cairo University The approval code for this study is:161022.

\section{REFERENCES}

1. Sirajuddin S, Narasappa KM, Gundapaneni V, Chungkham S, Walikar AS. latrogenic damage to periodontium by restorative treatment procedures: an overview. Open Dent J. 2015;9:217-22.

2. Murray PE, García Godoy C, García Godoy F. How is the biocompatibilty of dental biomaterials evaluated? Med Oral Patol Oral Cir Bucal. 2007;12(3):E258-E66.

3. Broadbent JM, Williams KB, Thomson WM, Williams SM. Dental restorations: a risk factor for periodontal attachment loss? J Clin Periodontol. 2006;33(11):803-10.

4. Litonjua LA, Cabanilla LL, Abbott LJ. Plaque formation and marginal gingivitis associated with restorative materials. Compend Contin Educ Dent. 2012;33(1):e6-10.

5. Isler SC, Ozcan G, Akca G, Kocabas Z. The effects of different restorative materials on periodontopathogens in combined restorative-periodontal treatment. J Appl Oral Sci. 2018;26:e20170154.

6. Cigu AT, Ciobanu C, Covalciuc E, Popovici M, Cârligeanu L, Ardeshir S. Research of BioHPP system behavior in the oral cavity. Inter J Med Dent. 2015;5(1):44-51.

7. Bechir ES, Bechir A, Cherana G, Manu R, Burcea A, Dascalu IT. The advantages of BioHPP polymer as superstructure material in oral implantology. Materials Plastics. 2016;53(3):394-8.

8. Georgiev J, Vlahova A, Kissov H, Aleksandrov S, Kazakova R. Possible application of BioHPP in prosthetic dentistry: A literature review. J IMAB. 2018;24(1):1896-8.

9. Zoidis P, Papathanasiou I, Polyzois G. The Use of a modified Poly-Ether-EtherKetone (PEEK) as an alternative framework material for removable dental prostheses. A clinical report. J Prosthodont. 2016;25(7):580-4.

10. Brandt S, Winter A, Lauer HC, Kollmar F, Portscher-Kim SJ, Romanos GE. IPS e.max for all-ceramic restorations: clinical survival and success rates of full-coverage crowns and fixed partial dentures. Materials (Basel). 2019;12(3):462.

11. Gehrt M, Wolfart S, Rafai N, Reich S, Edelhoff D. Clinical results of lithium-disilicate crowns after up to 9 years of service. Clin Oral Investig. 2013:17(1):275-84
12 Moharamzadeh K, Brook IM, Noort RV. Biocompatibility of resin-based dental materials. Materials. 2009;2(2):514-48.

13. Julious SA. Sample sizes for clinical trials. CRC Press; 2009 Aug 26.

14. Wolfart S, Eschbach S, Scherrer S, Kern M. Clinical outcome of three-unit lithium-disilicate glass-ceramic fixed dental prostheses: up to 8 years results. Dent Mater. 2009;25(9):e63-71.

15. Sealed Envelope Ltd. 2012. Power calculator for binary outcome equivalence trial [Internet]. [cited 2016 0ct 07].Available from: https://www. sealedenvelope.com/power/binary-equivalence.

16. Dhanraj $M$, Anand $S$, Ariga P.Evaluation of subgingival microflora in all ceramic restorations with subgingival heavy chamfer finish lines. J Indian Prosthodont Soc. 2013;13(1):19-23.

17. Al-Sinaidi A,Preethanath $R$. The effect of fixed partial dentures on periodontal status of abutment teeth. Saudi J Dental Res. 2014;5(2):104-8.

18. Marsh PD, Do T, Beighton D, Devine DA. Influence of saliva on the oral microbiota. Periodontol 2000. 2016;70(1):80-92.

19. Stock V, Wagner C, Merk S, Roos M, Schmidlin PR, Eichberger M, et al. Retention force of differently fabricated telescopic PEEK crowns with different tapers. Dent Mater J. 2016;35(4):594-600.

20. Heimer S, Schmidlin PR, Stawarczyk B. Effect of different cleaning methods of polyetheretherketone on surface roughness and surface free energy properties. J Appl Biomater Funct Mater. 2016;14(3):e248-e55.

21. Hannig M, Kriener L, Hoth-Hannig W, Becker-Willinger C, Schmidt H. Influence of nanocomposite surface coating on biofilm formation in situ. J Nanosci Nanotechnol. 2007;7(12):4642-8.

22. Chakrabarty RP, Karim MM. Anaerobic bacteria in oral cavities and dental health. Ann Dent Univ Malaya. 2018;25(1):11-6.

23. Dantas LC, da Silva-Neto JP, Dantas TS, Naves LZ, das Neves FD, da Mota AS. Bacterial adhesion and surface roughness for different clinical techniques for acrylic polymethyl methacrylate. Int J Dent. 2016;2016:8685796.

24. Bolat M, Bosinceanu DG, Sandu IG, Bosinceanu DN, SurlariZ, Balcos C, et al. Comparative study on the degree of bacterial biofilm formation of dental bridges made from three types of materials. Mater Plastice. 2019;56(1):144-7.

25. Juárez IA, Larroulet S, Ojeda M, Rosas C. Periodontal status of teeth restored with crowns and its contralateral homologue, Valdivia-Chile. J Oral Res. 2015;4(3):167-73

26. Shi M, Wei Y, Hu W, Nie Y, Wu X, Lu R. The subgingival microbiome of periodontal pockets with different probing depths in chronic and aggressive periodontitis: A Pilot Study. Front Cell Infect Microbiol. 2018;8:124.

\section{Esra'a Odeh}

